\title{
Serum Pepsinogens, Gastrin-17 and Helicobacter pylori Antibody in the Residents of Two Cities in China with Distinct Mortality Rates of Gastric Cancer
}

\author{
Kui-Cheng Zheng, ${ }^{1,2}$ Kazuo Aoki, ${ }^{3}$ Xiao-Qing Li, ${ }^{1}$ Shu-Guang Lin, ${ }^{1}$ Bing-Shan Wu, ${ }^{1}$ \\ Wen-Ling Zhong, ${ }^{1}$ Tie-Hui Chen, ${ }^{1}$ Song Lin, ${ }^{4}$ Jian-Wang You ${ }^{5}$ and Chang $\mathrm{Su}^{1}$ \\ ${ }^{1}$ Fujian Provincial Center for Disease Control and Prevention, Fuzhou, P.R. China \\ ${ }^{2}$ Fujian Medical University School of Public Health, Fuzhou, P.R. China \\ ${ }^{3}$ Department of Public Health and Hygiene, Graduate School of Medicine, University of the Ryukyus, Okinawa, \\ Japan \\ ${ }^{4}$ Fuan Center for Disease Control and Prevention, Fuan, P.R. China \\ ${ }^{5}$ Changle Center for Disease Control and Prevention, Changle, P.R. China
}

\begin{abstract}
Gastric cancer is one of the most common malignant tumors causing death in Fujian Province, China. However, the mortality of gastric cancer is greatly varied in different areas in Fujian; for example, the mortality in Changle City is 7.4 times higher than that in Fuan City. In this study, we compared the differences in serological parameters, pepsinogen (PG) I, PG II, gastrin-17 (G-17), and Helicobacter pylori (H. pylori) antibody, between the two cities. It has been reported that low serum PG I is correlated with atrophic gastritis, a high-risk condition for developing gastric cancer, while high serum G-17 has been used for serological detection of atrophic corpus gastritis. We recruited 224 healthy subjects in Changle and 229 healthy subjects in Fuan, matched in age and sex. The serum levels of PG II and G-17 were significantly higher in Changle than those in Fuan. Importantly, the frequency of the subjects with low serum PG I $(<25$ $\mu \mathrm{g} / \mathrm{L}$ ) was significantly higher in Changle than in Fuan, although the serum PG I levels were similar between the two cities. Moreover, the percentage of the subjects with high serum G-17 ( $\geq 2$ pmol/L) and the positive rate of serum IgG antibody against $H$. pylori were significantly higher in Changle than those in Fuan. The detected differences in these serological parameters are consistent with the notion that the prevalence of atrophic gastritis may be higher in Changle than in Fuan, which results in a higher risk condition for developing gastric cancer in Changle.
\end{abstract}

Keywords: atrophic gastritis; gastric cancer; gastrin; Helicobacter pylori antibody; pepsinogen

Tohoku J. Exp. Med., 2012 Dec, 228 (4), 289-294. (C) 2012 Tohoku University Medical Press

Although the mortality of gastric cancer has been decreased recently, gastric cancer is still ranked as the third most common malignant tumor causing death in Fujian Province (Fujian Provincial Center for Disease Control and Prevention 2011), which is located in south-eastern China with a population of approximately 36 millions. It has been shown that the mortality of gastric cancer varies greatly in different areas in Fujian Province. In 2008, the mortality of gastric cancer in Changle City was $42.37 / 100,000$. However, at the same time, in Fuan City which is about 250 $\mathrm{km}$ far from Changle City (Fig. 1), the mortality was only 5.70/100,000 (Fujian Provincial Center for Disease Control and Prevention 2009). The reason why the mortality of gastric cancer was marked different between the two cities remains unknown.

Serological parameters, such as pepsinogen I (PG I),
PG II, gastrin-17 (G-17), and Helicobacter pylori ( $H$. pylori) antibody, have been used to explore the state of the gastric mucosa in populations with contrasting gastric cancer risks (Varis et al. 1991; Aromaa et al. 1996; Uemura et al. 2001; Ohata et al. 2004; Malfertheiner et al. 2005; Watabe et al. 2005; Oishi et al. 2006). Many studies have indicated that serum PG is a useful biomarker reflecting the morphological and functional status of the gastric corpus mucosa (Kitahara et al. 1999; Varis et al. 2000; Broutet et al. 2003). PG I is secreted exclusively from the fundic glands (Samloff 1971), while PG II is secreted from the fundic glands, pyloric glands, and the proximal duodenal mucosa (Samloff and Liebman 1973). It has been revealed that the reduction in serum PG I is correlated well with the severity of atrophic gastritis (Borch et al. 1989), which is a well-known high-risk condition for developing gastric can-

Received May 31, 2012; accepted October 10, 2012. Published online October 27, 2012; doi: 10.1620/tjem.228.289.

Correspondence: Kui-Cheng Zheng, M.D., Ph.D., Fujian Provincial Center for Disease Control and Prevention, No. 76, Jin-Tai Road, Fuzhou, Fujian Province 350001, P.R. China.

e-mail: kuizheng@hotmail.com 


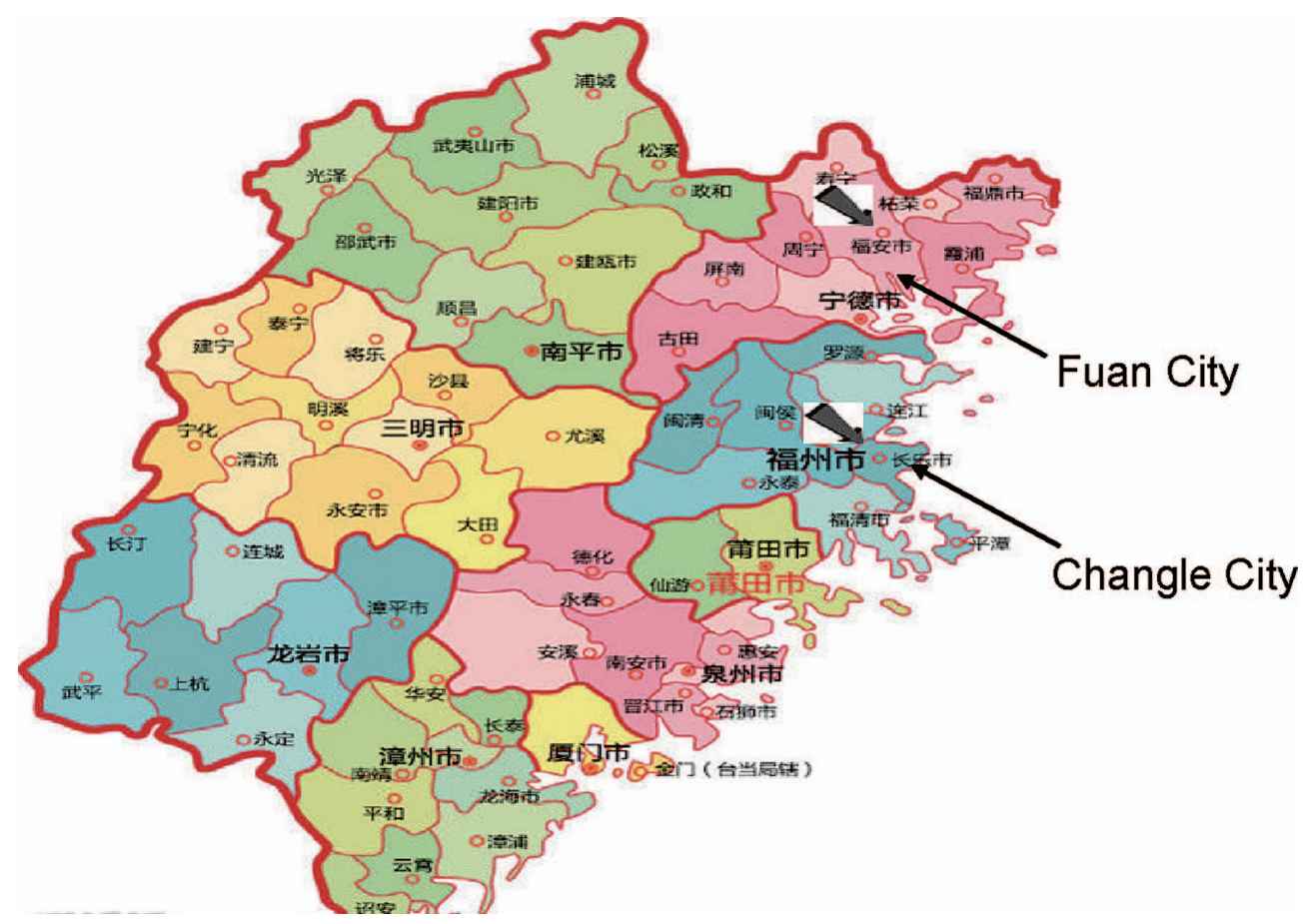

Fig. 1. The locations of Changle City and Fuan City.

Changle and Fuan are located in costal areas of Fujian Province, China.

cer. G-17 is exclusively secreted from antral G cells. In some previous studies, an increased level of serum G-17 was applied to screen gastric cancer through improving the serological detection of atrophic corpus gastritis (Shiotani et al. 2005; Rollan et al. 2006; Cao et al. 2007). Consequently, the measurement of serum PG in combination with serum G-17 can yield a topographic assessment of atrophic gastritis, potentially serving as a serological risk assessment of gastric cancer (Germaná et al. 2005; Cao et al. 2007; Kikuchi et al. 2011).

In order to explore underlying mechanisms of the great difference in mortality of gastric cancer between Changle and Fuan, in this study, we investigated whether or not the risk condition such as the prevalence of atrophic gastritis was different between Changle and Fuan through determination the serological profiles of serum PG I, PG II, G-17 and IgG antibody against $H$. pylori in the residents from the two cities.

\section{Material and Methods}

\section{Subjects}

The subjects involved in this study were native local residents aged from 30 to 70 years old and had been lived in the cities for at least 5 years. The persons with the presence of gastrointestinal symptom, history of medication such as antacid or PPI, history of $H$. pylori eradication were excluded from the study. The method of multi-stage random sampling was used in selecting the subjects. Firstly, one town with an average mortality of gastric cancer in Changle and Fuan was selected respectively, then four villages in each town were randomly selected. Finally about 55 subjects from 55 different families in each village were randomly selected. Totally 224 subjects in
Changle and 229 subjects in Fuan were recruited. The average ages of subjects in Changle City were $46.2 \pm 10.4$ years old, and $48.9 \pm$ 12.5 years old in Fuan City $(P<0.05)$. Among 224 subjects in Changle, male accounted for $116(51.8 \%)$ and female accounted for 108 (48.2\%), and among 229 subjects in Fuan, male subjects were $100(43.7 \%)$ and female were $129(56.3 \%)$. The proportion of male and female subjects in the two cities was not statistically different.

Each subject provided informed consent to participate in this study. To protect the subjects, this study was conducted according to the recommendations of the World Medical Association Helsinki Declaration (1989). The research protocol met the requirements for protection of human subject certification by the Ethic Committee of Fujian Provincial Center for Disease Control and Prevention, Fujian, China and University of the Ryukyus, Okinawa, Japan.

\section{Serum Sampling}

Fasting blood samples were taken from forearm veins by the medical staff of local hospital. After centrifugation, the serum specimens were stored at $-70^{\circ} \mathrm{C}$ until assay.

Determination of PG I, PG II, G-17 and IgG Antibody against $H$. pylori

Levels of serum PG I, PG II and G-17 were measured with ELISA kits from BIOHIT, Finland (PG I, Cat. No. 601010.01; PG II, Cat No. 601020.02; and G-17, Cat. No. 601035). Serum IgG antibody against $H$. pylori was measured with $H$. pylori IgG ELISA kit (Cat. No. 601040.02. BIOHIT, Finland) according to the instructions of manufacturer.

\section{Statistical Analysis}

The values of serum PG I, PG II, and G-17, and ratio of PG I to PG II (PG I/II ratio) were expressed by median, and were compared by using Mann-Whitney $U$ test. The Chi-square test and the Fisher's 
exact test were used to compare the positive rate of serum $\mathrm{IgG}$ antibody against $H$. pylori and the percentages of the subjects with low PG I $(<25 \mu \mathrm{g} / \mathrm{L})$, low PG I/II ratio $(<2.5)$ and high G-17 $(\geq 2 \mathrm{pmol} / \mathrm{L})$ between Changle and Fuan. For all tests, $P<0.05$ was considered as statistically significant. Analysis of data was performed using SPSS 13.0 (SPSS Inc., Chicago, IL, USA).

\section{Results}

Levels of serum PG I, PG II, and G-17, PG I/II ratio and positive rate of $\operatorname{Ig} G$ antibody against $H$. pylori

As shown in Table 1, the levels of PG II and G-17 were significantly higher in Changle than in Fuan $(P<$ $0.05)$, while PG I/II ratio was significantly lower in Changle than in Fuan $(P<0.05)$. The positive rate of serum IgG antibody against $H$. pylori was significantly higher in Changle than in Fuan $(P<0.05)$. The level of PG I was not significantly different between the two cities. Analysis by genders showed that both in male and in female, the levels of PG II and G-17 and positive rate of IgG antibody against H. pylori were significantly higher in Changle than in Fuan respectively $(P<0.05)$, while PG I/II ratio was significantly lower in Changle than in Fuan $(P<0.05)$ (Table 1). Moreover, further analysis by age groups showed that in each age group PG II and G-17 were significantly higher in
Changle than in Fuan $(P<0.05)$, but PG I/II ratio was significantly lower in Changle than in Fuan $(P<0.05)$. Except for 50-year-old group, the positive rates of $\operatorname{IgG}$ antibody against $H$. pylori in both 30 and 40-year-old groups were significantly higher in Changle than in Fuan $(P<0.05)$ (Table 2).

The percentage of the subjects with low PG I, low PG I/II ratio or high $\mathrm{G}-17$

According to the interpretation of the results from ELISA kits used in this study, the cut-off value of low PG I and low PG I/II ratio were $<25 \mu \mathrm{g} / \mathrm{L}$ and $<2.5$ respectively, and the cut-off value of high G-17 was $\geq 2 \mathrm{pmol} / \mathrm{L}$. The percentage of the subjects with low PG I or low PG I/II ratio was significantly higher in Changle than in Fuan, respectively $(P<0.05)$, but the percentage of the subjects with high $\mathrm{G}-17(\geq 2 \mathrm{pmol} / \mathrm{L})$ was significantly higher in Changle than in Fuan $(P<0.05)$. Similarly, in both male and female, the percentage of the subjects with low PG I or low PG I/II ratio was significantly higher in Changle than in Fuan respectively $(P<0.05)$. However, the percentage of the subjects with high G-17 was significantly higher in Changle than in Fuan $(P<0.05)$ (Table 3).

Table 1. Levels of serum PG I, PG II, G-17, and PG I/II ratios and positive rates of IgG antibody against $H$. pylori in Changle and Fuan.

\begin{tabular}{cccccccc}
\hline City & Gender & $\begin{array}{c}\text { Number of } \\
\text { Subjects }\end{array}$ & $\begin{array}{c}\text { PG I } \\
(\mu \mathrm{g} / \mathrm{L})\end{array}$ & $\begin{array}{c}\text { PG II } \\
(\mu \mathrm{g} / \mathrm{L})\end{array}$ & $\begin{array}{c}\text { PG I/II } \\
\text { ratio }\end{array}$ & $\begin{array}{c}\text { G-17 } \\
(\mathrm{pmol} / \mathrm{L})\end{array}$ & $\begin{array}{c}\text { Positive rate of } \\
\text { H. pylori antibody }(\%)\end{array}$ \\
\hline Changle & Male & 116 & 113.50 & $14.30^{1}$ & $7.59^{1}$ & 3.25 & 60.0 \\
& Female & 108 & 104.65 & 13.50 & 8.37 & 2.70 & 47.2 \\
& Total & 224 & 110.75 & $13.90^{2}$ & $7.91^{2}$ & 2.90 & 49.6 \\
\hline \multirow{2}{*}{ Fuan } & Male & 100 & 125.16 & $8.72^{*}$ & $13.78^{*}$ & $0.95^{*}$ & $25.0^{*}$ \\
& Female & 129 & 100.36 & $7.28^{*}$ & $12.26^{*}$ & $1.20^{* 3}$ & $32.6 *$ \\
& Total & 229 & 107.32 & $7.79^{*}$ & $13.09^{*}$ & $1.00^{*}$ & $29.3 *$ \\
\hline
\end{tabular}

PG I, PG II, PG I/II ratio and G-17 are represented by median. PG, pepsinogen and G-17, gastrin $17 . * P<0.05$ vs. Changle City. ${ }^{1-4}$ The numbers of subjects were ${ }^{1} 115,2223,{ }^{3} 127$, and ${ }^{4} 227$, respectively.

Table 2. Levels of serum PG I, PG II, G-17, and PG I/II ratios and positive rates of serum IgG antibody against $H$. pylori in different age groups in Changle and Fuan.

\begin{tabular}{cccccccc}
\hline City & $\begin{array}{c}\text { Age } \\
(\mathrm{yrs})\end{array}$ & $\begin{array}{c}\text { Number of } \\
\text { Subjects }\end{array}$ & $\begin{array}{c}\text { PG I } \\
(\mu \mathrm{g} / \mathrm{L})\end{array}$ & $\begin{array}{c}\text { PG II } \\
(\mu \mathrm{g} / \mathrm{L})\end{array}$ & $\begin{array}{c}\text { PG I/II } \\
\text { ratio }\end{array}$ & $\begin{array}{c}\text { G-17 } \\
(\mathrm{pmol} / \mathrm{L})\end{array}$ & $\begin{array}{c}\text { Positive rate of } \\
\text { H. pylori antibody }(\%)\end{array}$ \\
\hline \multirow{2}{*}{ Changle } & $30-$ & 76 & 109.60 & 13.60 & 8.54 & 2.85 & 48.7 \\
& $40-$ & 90 & 103.40 & $14.60^{1}$ & $7.11^{1}$ & 2.90 & 52.2 \\
& $50-$ & 58 & 137.10 & 12.75 & 8.47 & 3.10 & 46.6 \\
& Total & 224 & 110.75 & $13.90^{2}$ & $7.91^{2}$ & 2.90 & 49.6 \\
\hline \multirow{2}{*}{ Fuan } & $30-$ & 63 & 100.50 & $7.09^{*}$ & $13.18^{*}$ & $2.14^{3 *}$ & $23.8^{*}$ \\
& $40-$ & 98 & 113.38 & $7.79 *$ & $14.09^{*}$ & $1.00^{4 *}$ & $30.5^{*}$ \\
& $50-$ & 68 & 107.28 & $8.43^{*}$ & $12.47^{*}$ & $1.00^{*}$ & 32.4 \\
& Total & 229 & 107.32 & $7.79^{*}$ & $13.09^{*}$ & $1.00^{5 *}$ & $29.3 *$ \\
\hline
\end{tabular}

PG I, PG II, PG I/II ratio and G-17 are represented by median. PG, pepsinogen and G-17, gastrin $17 . * P<0.05$ vs. Changle City. ${ }^{1-5}$ The numbers of subjects were ${ }^{1} 89,{ }^{2} 223,{ }^{3} 62,497$, and ${ }^{5} 227$, respectively. 
K.C. Zheng et al.

Table 3. The percentages of the subjects with low PG I, low PG I/II ratio and high G-17 in Changle and Fuan.

\begin{tabular}{clccc}
\hline City & Gender & PG I $(<25 \mu \mathrm{g} / \mathrm{L})$ & PG I/II ratio $(<2.5)$ & G-17 $(\geq 2 \mathrm{pmol} / \mathrm{L})$ \\
\hline \multirow{2}{*}{ Changle } & Male & $6(5.2 \%)$ & $7(6.1 \%)^{1}$ & $78(67.2 \%)$ \\
& Female & $6(5.6 \%)$ & $9(8.3 \%)$ & $72(66.7 \%)$ \\
& Total & $12(5.4 \%)$ & $16(7.2 \%)^{2}$ & $150(67.0 \%)$ \\
\hline \multirow{2}{*}{ Fuan } & Male & $0(0 \%)^{*}$ & $0(0 \%)^{*}$ & $22(22.0 \%)^{*}$ \\
& Female & $0(0 \%)^{*}$ & $1(0.8 \%)^{*}$ & $37(29.1 \%)^{* 3}$ \\
& Total & $0(0 \%)^{*}$ & $1(0.4 \%)^{*}$ & $59(26.0 \%)^{* 4}$ \\
\hline
\end{tabular}

$\mathrm{PG}$, pepsinogen and G-17, gastrin 17. $* P<0.05$ vs. Changle. ${ }^{1-4}$ The numbers of subjects were ${ }^{1} 115$, $2223,{ }^{3} 117$, and ${ }^{4} 227$, respectively.

Table 4. Levels of serum PG I, PG II, G-17, and PG I/II ratio in the subjects with or without H. pylori infection in Changle and Fuan.

\begin{tabular}{llccccc}
\hline H.pylori Infection & \multicolumn{1}{c}{ City } & $\begin{array}{c}\text { Number of } \\
\text { Subjects }\end{array}$ & $\begin{array}{c}\text { PG I } \\
(\mu \mathrm{g} / \mathrm{L})\end{array}$ & $\begin{array}{c}\text { PG II } \\
(\mu \mathrm{g} / \mathrm{L})\end{array}$ & $\begin{array}{c}\text { PG I/II } \\
\text { ratio }\end{array}$ & $\begin{array}{c}\mathrm{G}-17 \\
(\mathrm{pmol} / \mathrm{L})\end{array}$ \\
\hline Positive & Changle & 111 & 121.10 & 15.80 & $7.32^{1}$ & 3.50 \\
& Fuan & 67 & 108.00 & $10.56^{*}$ & $8.46^{*}$ & $2.30^{*}$ \\
\hline Negative & Changle & 113 & 123.66 & 11.60 & 10.02 & 1.80 \\
& Fuan & 162 & 105.19 & $7.30^{*}$ & $14.22^{*}$ & $0.90^{* 2}$ \\
\hline
\end{tabular}

PG I, PG II, PG I/II ratio and G-17 are represented by median. PG, pepsinogen and G-17, gastrin 17 . $* P<0.05$ vs. Changle. ${ }^{1,2}$ The numbers of subjects were ${ }^{1} 110$ and ${ }^{2} 160$, respectively.

Table 5. The proportions of low PG I, low PG I/II ratio and high G-17 in the subjects with or without H. pylori infection in Changle and Fuan.

\begin{tabular}{lllll}
\hline H. pylori Infection & \multicolumn{1}{c}{ City } & $\begin{array}{c}\text { PG I } \\
(<25 \mu \mathrm{g} / \mathrm{L})\end{array}$ & $\begin{array}{c}\text { PG I/II ratio } \\
(<2.5)\end{array}$ & $\begin{array}{c}\text { G-17 } \\
(\geq 2 \mathrm{pmol} / \mathrm{L})\end{array}$ \\
\hline Positive & Changle $(n=111)$ & $5(4.5 \%)$ & $8(7.2 \%)$ & $88(79.3 \%)$ \\
& Fuan $(n=67)$ & $0(0 \%)$ & $1(1.5 \%)$ & $29(44.6 \%)^{* 1}$ \\
\hline \multirow{2}{*}{ Negative } & Changle $(n=113)$ & $7(6.2 \%)$ & $8(7.1 \%)^{2}$ & $62(54.9 \%)$ \\
& Fuan $(n=162)$ & $0(0 \%)^{*}$ & $0(0 \%)^{*}$ & $30(18.5 \%)^{*}$ \\
\hline
\end{tabular}

PG, pepsinogen and G-17, gastrin 17. $* P<0.05$ vs. Changle City. ${ }^{1,2}$ The numbers of subjects were ${ }^{1} 65$ and 2112 , respectively.

Levels of serum PG I, PG II, and G-17, and PG I/II ratio in the subjects with or without $H$. pylori infection

As shown in Table 4, the positive rate of IgG antibody against $H$. pylori in Changle was $49.5 \%$, which was significantly higher than that in Fuan $(29.2 \%)(P<0.05)$. In both the subjects with $H$. pylori infection and the subjects without $H$. pylori infection, the levels of PG II and G-17 were significantly higher in Changle than in Fuan $(P<0.05)$, while PG I/II ratio was significantly lower in Changle than in Fuan $(P<0.05)$. No significant difference was noted in PG I between Changle and Fuan.

The proportions of low PG I, low PG I/II ratio and high $G-17$ in the subjects with or without $H$. pylori infection

As shown in Table 5, in the subjects with $H$. pylori infection, the proportion of high G-17 was significantly higher in Changle than in Fuan $(P<0.05)$, but the proportion of low PG I or low PG I/II ratio was not significantly different between Changle and Fuan. In the subjects without $H$. pylori infection, the proportion of low PG I or low PG I/II ratio was significantly higher in Changle than in Fuan respectively $(P<0.05)$, while the proportion of high G-17 were significantly higher in Changle than in Fuan $(P$ $<0.05)$.

\section{Discussion}

In this study we measured serological parameters such as serum pepsinogens (PG I and PG II) and gastrin (G-17), as "biochemical biopsy" indicatives of the gastric mucosal histology in the subjects from Changle and Fuan. We also measured serum IgG antibody against $H$. pylori in the two cities. Generally the results showed that serum PG II and 
G-17 were significantly higher in Changle than in Fuan, but PG I/II ratio was significantly lower in Changle than in Fuan. These results might suggest that the prevalence of atrophic gastritis may be higher in Changle than in Fuan.

Our data further showed that the prevalence of $H$. pylori infection was significantly higher in Changle than in Fuan, which might support the hypothesis of a higher prevalence of atrophic gastritis in Changle. It has been reported that infection with $H$. pylori is a risk factor for gastric cancer (The Eurogast Study Group 1993; McFarlane and Munro 1997). H. pylori infection is the key determinant in fundic atrophy development (Adamu et al. 2011), which also affects pepsinogen and gastrin secretion (Gatta et al. 2011). H. pylori infection results in chronic gastritis that will develop into atrophic gastritis of some grade or type in half of infected subjects during their lifetime (Valle et al. 1996; Maaroos et al. 1999). Overall, our results suggested a higher risk condition for developing gastric cancer in the subjects from Changle as compared to those from Fuan.

In this study, in both the subjects with and without $H$. pylori infection, PG I/II ratio was significantly lower in Changle than in Fuan, but G-17 was significantly higher in Changle than in Fuan. Moreover, in the subjects without $H$. pylori infection, the proportions of low PG I $(<25 \mu \mathrm{g} / \mathrm{L})$ and low PG I/II ratio $(<2.5)$, but high G-17 $(\geq 2 \mathrm{pmol} / \mathrm{L})$ were significantly higher in Changle than in Fuan. These results implied that in addition to $H$. pylori infection, other factors might also account for the higher risk of gastric cancer in Changle. It has been suggested that genetic differences, dietary factors and life styles may influence the development of atrophic gastritis (Nomura et al. 1982; Howson et al. 1986; Kato et al. 1992). For example, high consumption of nitrite rich salty or low consumption of fresh fruits and raw vegetables may increase this risk (Nomura et al. 1982; Howson et al. 1986; Kato et al. 1992). Such dietary habits could be an independent risk factor for atrophic gastritis and could also have a synergistic effect with $H$. pylori infection. Although our data reveal that the expression of serological parameters is significantly different between Changle and Fuan, the exact reasons causing these differences remain unknown. One of the limitations of this study was that the sample size was rather small. Therefore, in order to explore the underlying mechanism why the risk of gastric cancer is different between Changle and Fuan, further study with a larger sample size should be carried out to investigate the dietary habits and life styles between the two cities.

In conclusion, this study suggests that the prevalence of atrophic gastritis may be higher in Changle than in Fuan, which results in a higher risk condition for developing gastric cancer in Changle.

\section{Acknowledgments}

The authors would like to thank Ms Dan-qing Zhang for her assistant in measurement of serum pepsinogen, gastrin and $H$. pylori antibody.

\section{Conflict of Interest}

The authors do not have any conflict of interest to declare.

\section{References}

Adamu, M.A., Weck, M.N., Rothenbacher, D. \& Brenner, H. (2011) Incidence and risk factors for the development of chronic atrophic gastritis: five year follow-up of a populationbased cohort study. Int. J. Cancer, 128, 1652-1658.

Aromaa, A., Kosunen, T.U., Knekt, P., Maatela, J., Teppo, L., Heinonen, O.P., Härkönen, M. \& Hakama, M.K. (1996) Circulating anti-Helicobacter pylori immunoglobulin A antibodies and low serum pepsinogen I level are associated with increased risk of gastric cancer. Am. J. Epidemiol., 144, 142-149.

Borch, K., Axelsson, C.K., Halgreen, H., Damkjaer Nielsen, M.D., Ledin, T. \& Szesci, P.B. (1989) The ratio of pepsinogen A to pepsinogen C: a sensitive test for atrophic gastritis. Scand. J. Gastroenterol., 24, 870-876.

Broutet, N., Plebani, M., Sakarovitch, C., Sipponen, P., Mégraud, F.; the Eurohepygast Study Group. (2003) Pepsinogen A, pepsinogen $\mathrm{C}$, and gastrin as markers of atrophic chronic gastritis in European dyspeptics. Br. J. Cancer., 88, 12391247.

Cao, Q., Ran, Z.H. \& Xiao, S.D. (2007) Screening of atrophic gastritis and gastric cancer by serum pepsinogen, gastrin-17 and Helicobacter pylori immunoglobulin G antibodies. J. Dig. Dis., 8, 15-22.

Fujian Provincial Center for Disease Control and Prevention. (2009) Report on Chronic Disease Surveillance in Fujian in 2008. 14-15.

Fujian Provincial Center for Disease Control and Prevention. (2011) Report on Chronic Disease Surveillance in Fujian in 2010. 12-14.

Gatta, L., Di Mario, F., Vaira, D., Rugge, M., Franzè, A., Plebani, M., Cavestro, GM., Lucarini, P., Lera, M. \& Scarpignato, C. (2011) Quantification of serum levels of pepsinogens and gastrin to assess eradication of Helicobacter pylori. Clin. Gastroenterol. Hepatol., 9, 440-442.

Germaná, B., Di Mario, F., Cavallaro, L.G., Moussa, A.M., Lecis, P., Liatoupolou, S., Comparato, G., Carloni, C., Bertiato, G., Battiestel, M., Papa, N., Aragona, G., Cavestro, G.M., Iori, V., Merli, R., Bertolini, S., Caruana, P. \& Franzé, A. (2005) Clinical usefulness of serum pepsinogens I and II, gastrin-17 and anti-Helicobacter pylori antibodies in the management of dyspeptic patients in primary care. Dig. Liver Dis., 37, 501-508.

Howson, C.P., Hiyama, T. \& Wynder, E.L. (1986) The decline in gastric cancer: epidemiology of an unplanned triumph. Epidemiol. Rev., 8, 1-27.

Kato, I., Tominaga, S., Ito, Y., Kobayashi, S., Yoshii, Y., Matsuura, A., Kameya, A., Kano, T. \& Ikari, A. (1992) A prospective study of atrophic gastritis and stomach cancer risk. Jpn. J. Cancer Res., 83, 1137-1142.

Kikuchi, R., Abe, Y., Iijima, K., Koike, T., Ara, N., Uno, K., Asanuma, K., Asano, N., Imatani, A. \& Shimosegawa, T. (2011) Low serum levels of pepsinogen and gastrin 17 are predictive of extensive gastric atrophy with high-risk of early gastric cancer. Tohoku J. Exp. Med., 223, 35-44.

Kitahara, F., Kobayashi, K., Sato, T., Kojima, Y., Araki, T. \& Fujino, M.A. (1999) Accuracy of screening for gastric cancer using serum pepsinogen concentrations. Gut, 44, 693-697.

Maaroos, H.I., Vorobjova, T., Sipponen, P., Tammur, R., Uibo, R., Wadström, T., Keevallik, R. \& Villako, K. (1999) An 18-year follow-up study of chronic gastritis and Helicobacter pylori association of CagA positivity with development of atrophy and activity of gastritis. Scand. J. Gastroenterol., 34, 864-869. 
Malfertheiner, P., Sipponen, P., Naumann, M., Moayyedi, P., Mégraud, F., Xiao, S.D., Sugano, K. \& Nyrén, O. (2005) Helicobacter pylori eradication has the potential to prevent gastric cancer: a state-of-the-art critique. Am. J. Gastroenterol., 100, 2100-2115.

McFarlane, G.A. \& Munro, A. (1997) Helicobacter pylori and gastric cancer. Br. J. Surg., 84, 1190-1199.

Nomura, A., Yamakawa, H., Ishidate, T., Kamiyama, S., Masuda, H., Stemmermann, G.N., Heilburn, L.K. \& Hankin, J.H. (1982) Intestinal metaplasia in Japan: association with diet. $J$. Natl. Cancer Inst., 68, 401-405.

Ohata, H., Kitauchi, S., Yoshimura, N., Mugitani, K., Iwane, M., Nakamura, H., Yoshikawa, A., Yanaoka, K., Arri, K., Tamai, H., Shimizu, Y., Takeshita, T., Mohara, O. \& Ichinose, M. (2004) Progression of chronic atrophic gastritis associated with Helicobacter pylori infection increases risk of gastric cancer. Int. J. Cancer, 109, 138-143.

Oishi, Y., Kiyohara, Y., Kubo, M., Tanaka, K., Tanizaki, Y., Ninomiya, T., Doi, Y., Shikata, K., Yonemoto, K., Shirota, T., Matsumoto, T. \& Iida, M. (2006) The serum pepsinogen test as a predictor of gastric cancer: the Hisayama study. Am. J. Epidemiol., 163, 629-637.

Rollan, A., Ferreccio, C., Gederlini, A., Serrano, C., Torres, J. \& Harris, P. (2006) Non-invasive diagnosis of gastric mucosal atrophy in an asymptomatic population with high prevalence of gastric cancer. World J. Gastroenterol., 12, 7172-7178.

Samloff, I.M. (1971) Cellular localization of group I pepsinogens in human gastric mucosa by immunofluorescence. Gastroenterology, 61, 185-188.

Samloff, I.M. \& Liebman, W.M. (1973) Cellular localization of the group II pepsinogens in human stomach and duodenum by immunofluorescence. Gastroenterology, 65, 36-42.
Shiotani, A., Iishi, H., Uedo, N., Kumamoto, M., Nakae, Y., Ishiguro, S., Tatsuta, M. \& Graham, D.Y. (2005) Histologic and serum risk markers for noncardia early gastric cancer. Int. J. Cancer, 115, 463-469.

The Eurogast Study Group. (1993) An international association between Helicobacter pylori infection and gastric cancer. Lancet, 341, 1359-1362.

Uemura, N., Okamoto, S., Yamamoto, S., Matsumura, N., Yamaguchi, S., Yamakido, M., Taniyama, K., Sasaki, N. \& Schlemper, R.J. (2001) Helicobacter pylori infection and the development of gastric cancer. N. Engl. J. Med., 345, 784789.

Valle, J., Kekki, M., Sipponen, P., Ihamäki, T. \& Siurala, M. (1996) Long-term course and consequences of Helicobacter pylori gastritis. Results of a 32-year follow-up study. Scand. J. Gastroenterol., 31, 546-550.

Varis, K., Kekki, M., Härkönen, M., Sipponen, P. \& Samloff, I.M. (1991) Serum pepsinogen I and serum gastrin in the screening of atrophic pangastritis with high risk of gastric cancer. Scand. J. Gastroenterol. Suppl., 186, 117-123.

Varis, K., Sipponen, P., Laxén, F., Samloff, I.M., Huttunen, J.K., Taylor, P.R., Heinonen, O.P., Albanes, D., Sande, N., Virtamo, J. \& Härkönen, M. (2000) Implications of serum pepsinogen I in early endoscopic diagnosis of gastric cancer and dysplasia. Helsinki Gastritis Study Group. Scand. J. Gastroenterol., 35, 950-956.

Watabe, H., Mitsushima, T., Yamaji, Y., Okamoto, M., Wada, R., Kokubo, T., Doi, H., Yoshida, H., Kawabe, T. \& Omata, M. (2005) Predicting the development of gastric cancer from combining Helicobacter pylori antibodies and serum pepsiogen status: a prospective endoscopic cohort study. Gut, 54, 764-768. 